
RESEARCH AND DEVELOPMENT

\author{
http://journal.unnes.ac.id/sju/index.php/higeia
}

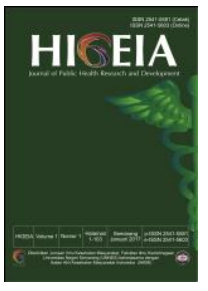

\title{
Pola Asuh dan Peer Group terhadap Konsep Diri Remaja tentang Perilaku Seksual
}

\author{
Najib $^{1 凶}$, Bambang Budi Raharjo ${ }^{2}$ \\ ${ }^{1}$ Bagian Penelitian dan Pengembangan, Perwakilan BKKBN Provinsi Jawa Tengah, Indonesia \\ ${ }^{2}$ Jurusan Ilmu Kesehatan Masyarakat, Fakultas Ilmu Keolahragaan, Universitas Negeri Semarang, Indonesia
}

\begin{abstract}
Info Artikel
Abstrak

Sejarah Artikel:

Diterima 8 September

2018

Disetujui 19 Oktober

2018

Dipublikasikan 30

Oktober 2018

Keywords:

Parenting, Youth

Development,

Adolescent Sexual Behavior

DOI:

https://doi.org/10.15294

/higeia.v2i4.26931

Masa remaja merupakan masa dimana seorang individu mengalami peralihan yang penuh dengan permasalahan. Salah satu permasalahan pada remaja yang berisiko adalah masalah perilaku seksual remaja. Faktor yang memengaruhi perilaku reproduksi remaja diantaranya adalah faktor keluarga dan pergaulan remaja. Penelitian ini bertujuan untuk mengetahui pengaruh pola asuh orangtua dan peer group terhadap konsep diri remaja tentang perilaku seksual pada siswa SMK. Jenis penelitian ini survei analitik dengan desain penelitian cross sectional. Responden penelitian ini adalah siswa/siswi dan orangtua SMK Negeri di Kota Semarang sebanyak 387 orang dan diambil dengan purposive sampling. Analisis bivariat menggunakan uji Chi Square. Hasil menunjukkan Peer group Buruk (73,8), Pola Asuh orangtua Otoriter (57,9\%), dan Konsep Diri Baik $(68,3)$. Uji statistik menunjukkan adanya hubungan Peer group dengan konsep diri remaja tentang perilaku seksual di SMK Negeri di Kota Semarang $(P=0,009 ; C=0,134), 35,5 \%$ konsep diri Buruk dengan peer group yang buruk. Ada hubungan Pola Asuh Orang Tua dengan konsep diri remaja tentang perilaku seksual di SMK Negeri di Kota Semarang $(P=0,003 ; C=0,153), 37,9 \%$ pola asuh otoriter mengakibatkan konsep diri yang buruk. Penelitian ini menyimpulkan bahwa pola asuh orang tua dan peer group berhubungan dengan konsep diri remaja terkait perilaku seksual.
\end{abstract}

\section{Abstract}

The period for the future of individual transition is full of problems. One of the problems in adolescents who are at issue is the problem of adolescent governance. Factors that influence adolescents are family factors and teenage relationships. This study aimed to determine the effect of parenting and peer grouping on adolescent self-concept about sexual behavior in vocational students. This type of research was analytic survey with cross sectional research design. Respondents of this study were 387 public vocational high school students in Semarang City and taken by purposive sampling. Bivariate analysis used Chi Square test. The results showed the Poor Group (73.8), the Authoritarian Asuhahulu Pattern (57.9\%), and the Good Self Concept (68.3). Statistical test shows that there is a relationship between Peer group and adolescent self-concept in Semarang City State Vocational High School $(P=0.009 ; C=0.134), 35.5 \%$ Bad self concept with poor peer group. There is a relationship between parenting and self-concept in state vocational schools in the city of Semarang $(P$ $=0.003 ; C=0.153), 37.9 \%$ authoritarian parenting that is bad. This study concluded that parenting and peer group were related to sexual concepts.

(C) 2018 Universitas Negeri Semarang

Alamat korespondensi:

Latbang Perwakilan BKKBN Prov.Jawa Tengah

p ISSN 1475-362846

J1. Pemuda 79 Semarang

e ISSN 1475-222656

E-mail: iibpenkb@gmail.com 


\section{PENDAHULUAN}

Masa remaja merupakan masa dimana seorang individu mengalami peralihan dari satu tahap ke tahap berikutnya dan mengalami perubahan baik dari segi emosi, tubuh, minat pola perilaku, yang penuh dengan permasalahan. Perubahan fisik yang dialami remaja berhubungan dengan diproduksinya hormone seksual dalam tubuh mengakibatkan timbulnya dorongan emosi dan seksual. Hal ini menjadi titik rawan karena remaja mempunyai kecenderungan untuk mencoba hal-hal yang belum diketahuinya berkaitan dengan perubahan yang dialaminya sehingga diharapkan perlu informasi yang positif ke remaja. Dalam perkembangannya, remaja sangat rentan terhadap pengaruh lingkungan. Lingkungan sosial yang tidak baik merupakan faktor risiko bagi remaja untuk terjebak dalam perilaku yang tidak sehat, misalnya merokok, minum minuman keras, penggunaan narkoba, seks pranikah, tawuran, tindakan kriminal. Salah satu permasalahan pada remaja yang berisiko adalah masalah perilaku seksual remaja yang dalam skala nasional ditunjukkan dari Hasil survey yang dilakukan di 5 kota besar menunjukkan bahwa 39\% responden sudah pernah berhubungan seksual saat masih remaja usia 15-19 tahun, sisanya $61 \%$ berusia $20-25$ tahun (Amaliyasari, 2008).

Perilaku seks, khususnya kalangan remaja Indonesia sungguh memperihatinkan. Menurut data, sebanyak $63 \%$ remaja di beberapa kota besar di Indonesia telah melakukan seks pra nikah. Hubungan seks yang mereka lakukan ini juga dilandasi pemikiran bahwa berhubungan seks satu kali tidak menyebabkan kehamilan. Sementara data menunjukkan bahwa 42,3\% remaja SMP dan SMA di Cianjur, Jawa Barat, melakukan hubungan seks yang pertama di bangku sekolah dan melakukannya berdasarkan rasa suka dan tanpa paksaan. Terkait dengan kasus aborsi sebagai imbas dari hubungan seksual pada remaja. Persatuan Keluarga Berencana Indonesia (PKBI) mengemukakan fakta dari 37.685 pelaku aborsi, $27 \%$ belum menikah dan sudah mengupayakan upaya aborsi terlebih dahulu sendiri, seperti minum jamu, tetapi gagal. Sementara data dari lembaga Kisara, Bali, tercatat kehamilan yang tidak diinginkan pada remaja cenderung meningkat antara 150.000 hingga 200.000 kasus per tahunnya (BKKBN, 2008).

Banyaknya media informasi dalam era globalisasi ini memungkinkan remaja memperoleh kemudahan dalam mencari informasi yang dibutuhkan baik informasi positif maupun negatif dalam pergaulan remaja. Dengan begitu mudahnya mendapatkan informasi mengakibatkan banyak ditemuinya remaja yang melakukan perilaku negatif dan tindakan kriminal, kemajuan pesat di samping merupakan peluang juga dapat berupa ancaman bagi remaja jika informasi yang diperoleh tidak benar. Faktor yang memengaruhi perilaku reproduksi remaja diantaranya adalah faktor keluarga. Hubungan orangtua remaja, mempunyai pengaruh langsung dan tidak langsung dengan perilaku seksual pranikah remaja (Mertia, 2011).

Hasil penelitian menunjukkan, makin baik hubungan orangtua dengan anak remajanya, makin rendah perilaku seksual pranikah remaja. Faktor-faktor yang memengaruhi perilaku seksual pranikah pada remaja paling tinggi adalah hubungan antara orangtua dengan remaja, tekanan peer group, pemahaman tingkat agama (religiusitas), dan eksposur dari media pornografi. Proses pembentukan seorang individu dalam sebuah keluarga adalah karena keluarga merupakan tempat pertama dan utama seorang individu memperoleh pendidikan dan keterampilan untuk bekal hidupnya di masa yang akan datang. Orangtua memberikan pendidikan kepada anaknya melalui proses pengasuhan. Hurlock menyatakan bahwa peran orangtua terhadap anak merupakan hal yang sangat penting dalam proses tumbuh kembang anak (Munawaroh, 2012).

Sunarti mengemukakan bahwa pola asuh merupakan perilaku orangtua yang paling menonjol atau yang paling dominan dalam menangani anaknya sehari-hari, termasuk pola orangtua dalam mendisiplinkan anak, 
menanamkan nilai-nilai hidup, mengajarkan keterampilan hidup, dan mengelola emosi sehingga membentuk konsep diri. Tetapi pada kenyataannya remaja lebih banyak berada diluar rumah bersama dengan peer group. Jadi jelaslah bahwa perilaku peer group lebih besar pengaruhnya dari pada keluarga. Didalam peer group remaja berusaha menemukan konsep dirinya. Peer group memberikan lingkungan, dimana remaja dapat melakukan sosialisasi dengan teman seusianya. Akan tetapi sangat berbahaya apabila kelompok sebaya ini cendrung tertutup, dimana setiap anggota tidak dapat terlepas dari kelompoknya dan harus mengikuti nilai yang dikembangkan oleh pimpinan kelompok, sikap, pikiran, perilaku dan gaya hidupnya merupakan perilaku dan gaya hidup kelompoknya (Nursal, D. G. 2008).

Berdasarkan hasil observasi di SMK XX terdapat 306 siswa, dimana 110 siswa kelas $\mathrm{X}$ jurusan akuntansi, pemasaran, animasi. 84 siswa kelas XI jurusan akuntansi, pemasaran, animasi dan 112 siswa kelas XII jurusan akuntansi, animasi. Fenomena yang terjadi di SMK XX tiap tahunnya ditemukan kasus kehamilan pranikah sekitar 1 sampai 2 anak.

Perbedaan penelitian ini dengan penelitian sebelumnya yaitu belum ada penelitian terkait hal ini dengan sasaran responden anak sekolah SMK di daerah dekat lokalisasi. Sehingga penelitian ini bertujuan untuk mengetahui pengaruh pola asuh orangtua dan peer group terhadap konsep diri remaja tentang perilaku seksual pada siswa SMK.

\section{METODE}

Penelitian dengan pendekatan potong lintang (cross sectional), yang bertujuan mengetahui pengaruh pola asuh orangtua dan peer group terhadap konsep diri remaja tentang perilaku seksual, dimana pengukuran atau pengamatan dilakukan pada saat bersamaan pada data variabel bebas dan terikat (sekali waktu). Populasi penelitian ini adalah siswasiswi SMK kelas X, XI, dan XII di kota Semarang. Dari data Dinas Pendidikan Kota Semarang, jumlah siswa-siswi SMK sebanyak
8882 orang. Berdasarkan perhitungan didapatkan jumlah sampel yang diteliti sebanyak 378 siswa/siswi. Selanjutnya data dianalisa secara statistic univariat dan bivariat.

\section{HASIL DAN PEMBAHASAN}

Sebagian besar responden yaitu memiliki jenis kelamin perempuan yaitu sebanyak 210 orang $(55,6 \%)$. Hal tersebut terjadi karena SMK Negeri di Semarang lebih banyak memiliki siswa berjenis kelamin perempuan, sehingga memungkinkan mendapatkan responden berjenis kelamin perempuan yang lebih banyak. Peran jenis kelamin adalah bagian dari peran sosial pula dan tidak hanya ditentukan oleh jenis kelamin orang yang bersangkutan, tetapi oleh lingkungan dan faktor-faktor lainnya.

Fungsi seksual remaja perempuan lebih cepat matang dari pada remaja laki-laki, tetapi pada perkembangannya remaja laki-laki lebih aktif secara seksual dari pada remaja perempuan, hal ini dikarenakan adanya perbedaan sosialisasi seksual antara remaja perempuan dengan remaja laki-laki (Pratami, 2011).

Pendidikan orangtua yang didalamnya terdapat pendidikan ayah dan ibu, pada keduanya menggambarkan hasil yang sama yaitu pendidikan terakhir ayah dan ibu paling banyak adalah SLTA yaitu $46,6 \%$ pada ayah dan $47,9 \%$ pada ibu.

Latar belakang pendidikan orang tua mempunyai pengaruh yang besar terhadap pembentukan kepribadian anak. Orang tua yang mempunyai latar belakang pendidikan yang tinggi akan lebih memperhatikan segala perubahan dan setiap perkembangan yang terjadi pada anaknya. Orang tua yang berpendidikan tinggi umumnya mengetahui bagaimana tingkat perkembangan anak dan bagaimana pengasuhan orang tua yang baik sesuai dengan perkembangan anak khususnya untuk pembentukan kepribadian yang baik bagi anak. Orang tua yang berpendidikan tinggi umumnya dapat mengajarkan sopan santun kepada orang lain, baik dalam berbicara ataupun dalam hal lain. Berbeda dengan orang 
tua yang mempunyai latar belakang pendidikan yang rendah. Dalam pengasuhan anak umumnya orang tua kurang memperhatikan tingkat perkembangan anak. Hal ini dikarenakan orang tua yang masih awam dan tidak mengetahui tingkat perkembangan anak. Bagaimana anaknya berkembang dan dalam tahap apa anak pada saat itu. Orang tua biasanya mengasuh anak dengan gaya dan cara mereka sendiri, apa yang menurut mereka baik untuk anaknya. Anak dengan pola asuh orang tua yang seperti ini akan membentuk suatu kepribadian yang kurang baik (Respati, 2006).

Sebagian besar orangtua responden dalam penelitian ini memiliki pendidikan yang tinggi sehingga diharapkan dapat memberikan pengasuhan terhadap anaknya lebih baik dibandingkan dengan yang berpendidikan rendah.

Berdasarkan karakteristik pekerjaan orangtua, sebagian besar pekerjaan ayah yaitu swasta $44,4 \%$ dan pada pekerjaan ibu yang paling banyak adalah tidak bekerja atau menjadi ibu rumah tangga sebanyak $48,4 \%$.

Pembentukan Kepribadian Anak dari sikap, kebiasaan dan pola perilaku yang dibentuk selama tahun-tahun pertama, sangat menentukan seberapa jauh individu-individu berhasil menyesuaikan diri dalam kehidupan ketika mereka bertambah tua. Kenyataan tersebut menyiratkan betapa pentingnya dasardasar yang diberikan orang tua pada anaknya pada masa kanak-kanak. Karena dasar-dasar inilah yang akan membentuk kepribadian yang dibawa sampai masa tua. Tidak dapat dipungkiri kesempatan pertama bagi anak untuk mengenal dunia sosialnya adalah dalam keluarga. Didalam keluarga untuk pertama kalinya anak mengenal aturan tentang apa yang baik dan tidak baik (Suwarni, 2009).

Oleh karena itu, orang tua harus bisa memberikan pendidikan dasar yang baik kepada anak-anaknya agar nantinya bisa berkembang dengan baik. Kenyataan yang terjadi pada masa sekarang adalah berkurangnya perhatian orang tua terhadap anaknya karena keduanya samasama bekerja. Hal tersebut mengakibatkan terbatasnya interaksi orang tua dengan anaknya.
Keadaan ini biasanya terjadi pada keluargakeluarga muda yang semuanya bekerja. Anakanak kurang mendapatkan perhatian dan kasih sayang dari orang tua karena keduanya samasama sibuk dengan pekerjaannya masingmasing. Sedangkan anak pada usia ini sangat mambutuhkan perhatian lebih dari orang tua terutama untuk perkembangan kepribadian. Anak yang ditinggal orang tuanya dan hanya tinggal dengan seorang pengasuh yang dibayar orang tua untuk menjaga dan mengasuh, belum tentu anak mendapatkan pengasuhan yang baik sesuai perkembangannya dari seorang pengasuh. Anak yang ditinggal kedua orang tuanya bekerja cenderung bersifat manja. Biasanya orang tua akan merasa bersalah terhadap anak karena telah meninggalkan anak seharian. Sehingga orang tua akan menuruti semua permintaan anak untuk menebus kesalahanya tersebut tanpa berfikir lebih lanjut permintaan anak baik atau tidak untuk perkembangan kepribadiaan anak selanjutnya. Kurangnya perhatiaan dari orang tua akan mengakibatkan anak mencari perhatian dari luar, baik dilingkungan sekolah dengan teman sebaya ataupun dengan orang tua pada saat mereka di rumah. Anak suka mengganggu temannya ketika bermain, membuat keributan di rumah dan melakukan hal-hal yang terkadang membuat kesal orang lain. Semua perlakuan anak tersebut dilakukan hanya untuk menarik perhatian orang lain karena kurangnya perhatian dari orangtua. Sedangkan orang tua yang tidak bekerja di luar rumah akan lebih fokus pada pengasuhan anak dan pekerjaan rumah lainnya. Anak sepenuhnya mendapatkan kasih sayang dan perhatian dari orang tua. Akan tetapi tidak menutup kemungkinan anak menjadi kurang mandiri, karena terbiasa dengan orang tua. Segala yang dilakukan anak selalu dengan pangawasan orang tua. Oleh karena itu, orang tua yang tidak bekerja sebaiknya juga tidak terlalu over protektif. Sehingga anak mampu untuk bersikap mandiri (Widyastuti, E. S. A. 2009).

Pada usia remaja, kelompok sepermainan berkembang menjadi kelompok persahabatan yang lebih luas. Dalam istilah sosiologi, 
kelompok bermain atau teman sebaya dikenal dengan sebutan "peer group". Teman atau persahabatan merupakan pengelompokan sosial yang melibatkan orang-orang yang berhubungan relatif akrab satu sama lain. Kelompok teman sebaya sebagai lingkungan sosial bagi remaja menjadi peranan penting bagi perkembangan kepribadiannya (Fatchurahman, 2012).

Hasil penelitian menunjukkan bahwa lebih banyak ditemukan peer group yang buruk dibandingkan yang baik sebanyak 279 orang $(73,8 \%)$. Dari observasi yang dilakukan, peneliti melihat bahwa terdapat kecenderungan pada siswa untuk saling mengelompok atau membentuk geng, sehingga apa yang dilakukan oleh salah satu orang dari dalam kelompok yang lebih dominan akan berpengaruh kepada siswa lainnya termasuk hal positif maupun negatif didalamnya. Hal ini terjadi sebab ada tekanan secara tidak langsung dalam lingkungan pergaulan yang terbentuk.

Hal ini sesuai dengan pernyataan yang menyatakan bahwa terdapat lima jenis peer group yaitu teman dekat, kelompok kecil, kelompok besar, kelompok terorganisir, dan geng (Fatchurahman, 2012).

Pola asuh orangtua merupakan segala bentuk dan proses interaksi yang terjadi antara orangtua dan anak yang merupakan pola pengasuhan tertentu dalam keluarga yang akan memberi pengaruh terhadap perkembangan kepribadian anak. Orang tua dengan pola asuh ini bersikap rasional, selalu mendasari tindakannya pada rasio atau pemikiranpemikiran. Orang tua pada tipe ini juga bersifat realistis terhadap kemampuan anak, tidak berharap yang berlebihan yang melampaui kemampuan anak. Orang tua tipe ini juga memberikan kebebasan kepada anak untuk memilih dan melakukan suatu tindakan dan pendekatan kepada anaknya bersikap hangat. Karakteristik anak-anak dengan pola asuh ini akan menghasilkan anak dengan karakteristik mandiri, dapat mengontrol diri, mempunyai hubungan baik dengan teman, mampu menghadap stress, mempunyai minat terhadap hal-hal baru dan dapat kooperatif terhadap orang lain (Desiyanti, 2015).
Hasil penelitian menunjukkan lebih banyak ditemukan orang yang bersikap otoriter yaitu 219 orang $(57,9 \%)$ dibandingkan yang memilih bersikap demokratis. Hal ini dapat disebabkan karena orangtua siswa dan siswi menyadari bahwa pergaulan remaja pada zaman sekarang sudah terlalu bebas dan tidak mengenal batas. Sebagian besar orangtua yang rata-rata memiliki pendidikan terakhir SLTA/sederajat hanya memahami konsep bahwa pendidikan seks adalah sesuatu yang tabu dan tanpa manfaat jika dipelajari, oleh karena itu mereka lebih memilih untuk bersikap otoriter sebagai pencegahan atas hal yang tidak diinginkan.

Konsep diri terbentuk melalui proses belajar sejak masa pertumbuhan seorang manusia sejak kecil hingga dewasa. Lingkungan, pengalaman dan pola asuh orang tua turut memberikan pengaruh yang signifikan terhadap konsep diri yang terbentuk. Sikap atau respon orang tua dari lingkungan akan menjadi bahan informasi bagi anak untuk menilai siapa dirinya. Perkembangan konsep diri adalah proses sepanjang hidup (Rahmania, 2006).

Perkembangan seseorang selain ditentukan oleh kondisi dirinya, juga dikaitkan dengan kehidupan kelompok dalam lingkungan masyarakatnya pada setiap tahap perkembangan yang dilaluinya.

Konsep diri belum ada saat lahir, kemudian berkembang secara bertahap sejak lahir seperti mulai mengenal dan membedakan dirinya dan orang lain. Dalam melakukan kegiatannya memiliki batasan diri yang terpisah dari lingkungan dan berkembang melalui kegiatan eksplorasi lingkungan melalui bahasa, pengalaman atau pengenalan tubuh, nama panggilan, pangalaman budaya dan hubungan interpersonal, kemampuan pada area tertentu yang dinilai oleh diri sendiri atau masyarakat serta aktualisasi diri dengan merealisasi potensi yang nyata (Hidayangsih, 2011).

Dimana konsep diri dipelajari melalui kontak dan pengalaman dengan orang lain, belajar diri sendiri melalui cermin orang lain yaitu dengan cara pandangan diri merupakan interprestasi diri pandangan orang lain terhadap 
diri, anak sangat dipengaruhi orang yang dekat, remaja dipengaruhi oleh orang lain yang dekat dengan dirinya, pengaruh orang dekat atau orang penting sepanjang siklus hidup, pengaruh budaya dan sosialisasi.

Konsep diri dapat dibentuk melalui pandangan diri dan pengalaman yang positif. Sehingga konsep merupakan aspek yang kritikal dan dasar dari prilaku individu. Individu dengan konsep diri yang positif dapat berfungsi lebih efektif yang dapat berfungsi lebih efektif yang dapat dilihat dari kemampuan interpersonal, kemampuan intelektual dan penguasaan lingkungan. Sedangkan konsep diri yang negatif dapat dilihat dari hubungan individu dan sosial yang terganggu.

Dari hasil penelitian yang dilakukan terdapat lebih banyak siswa dengan konsep diri yang baik 258 orang $(68,3 \%)$, hal ini menunjukkan bahwa siswa sudah paham mengenai pergaulan remaja yang positif dan negatif serta dapat memilih dan menempatkan dirinya dalam lingkungan sosial. Peneliti juga menyimpulkan bahwa banyak terdapatnya konsep diri yang baik dikarenakan kurang adanya pemahaman dalam konsep seksualitas sehingga terdapat kecenderungan untuk menghindari atau tidak melakukan walaupun mereka menyadari lingkungan sekitarnya masih sangat mempengaruhi, sehingga masih perlu adanya pendampingan dalam pembelajaran yang benar mengenai hal tersebut.

Mengkaji persahabatan dikalangan kelompok teman sebaya remaja, banyak hasil penelitian menunjukan bahwa faktor utama yang menentukan daya tarik hubungan interpersonal diantara para remaja adalah minat, nilai-nilai, pendapat dan sifat-sifat (kepribadian), sama halnya dalam hasil dilapangan yang menemukan sebagian besar siswa lebih memilih teman yang memiliki hobi sama dan lebih mudah menirukan gaya teman dalam pergaulannya. Sedangkan disekolah (dan sejenisnya) dipengaruhi oleh kesamaankesamaan faktor antara lain : harapan atau aspirasi pendidikan, nilai (prestasi belajar), absen, dan PR atau tugas. Penelitian Kandel menunjukan bahwa karakteristik persahabatan para remaja tidak lagi dipengaruhi oleh kesamaan usia, jenis kelamin, ataupun ras (Batubara, 2016).

Pengaruh pertemanan sebaya sangat tinggi dikalangan remaja, dimana teman sebaya yang baik akan mempengaruhi konsep diri yang baik pula dalam hal apapun juga dalam hal perilaku seksual, serta sebaliknya. Sehingga hasil analisa penelitian adalah ada hubungan Peer group dengan konsep diri remaja tentang perilaku seksual di SMK Negeri di Kota Semarang. Hal ini sama dengan penelitian Fronge, Roswita Loma bahwa ada hubungan yang positif yang sangat signifikan antara konformitas teman sebaya dengan perilaku seksual pada remaja.

Selain berteman dalam suatu kelompok, remaja juga pasti membutuhkan teman secara individual seperti teman untuk berbagi (sharing), teman akrab ataupun seorang pacar. Dalam pergaulan dengan teman secara individual tentu saja berbeda dengan norma pergaulan dalam kelompok. Persahabatan individual pun tidak menutup kemungkinan terjadi pada anggota kelompok, anggota kelompok dengan anggota kelompok lain atau sesama bukan anggota kelompok. Persahabatan secara individual menjadi penting dimana remaja dan berinteraksi interpersonal yang lebih intim dan mereka biasanya memilih teman akrab yang benar-benar sesuai dengan kepribadian dan yang dapat memahami keadaan dirinya (Dewi, 2010).

Orangtua sebagai lingkungan sosial pertama remaja diharapkan dapat menerapkan pola asuh yang mengutamakan adanya dialog yang terbuka antara remaja dan orang tua tentang kesehatan reproduksi sehingga remaja memiliki sikap yang benar tentang kesehatan reproduksi. Namun pada kenyataannya orang tua seringkali menganggap tabu pembicaraan tentang fungsi dan proses reproduksi serta seksualitas kepada remaja, akhirnya remaja berusaha mencari informasi lewat media massa dan teman-temannya sehingga mereka kadangkadang memperoleh informasi yang kurang tepat, malah terkadang menyesatkan dan menjerumuskan mereka sendiri.Oleh karena itu 
pola asuh orang tua sangat penting untuk membentuk konsep diri remaja (Gainau, 2009).

Remaja menginginkan orang tua yang menaruh perhatian dan siap membantu apabila remaja membutuhkan bantuan serta mendengarkan dan berusaha mengerti sebagai remaja; menunjukan bahwa mereka menyetujui remaja ; menerima apa adanya; memperlakukan sang remaja dengan dewasa dan yang paling penting menjadi teladan baik bagi remaja.

Dalam setiap keluarga ada nilai-nilai atau aturan yang harus dipegang atau ditaati oleh setiap anggota keluarga termasuk anak remaja itu sendiri. Namun bila setiap aturan tidak disampaikan dengan baik maka akan terjadi pelanggaran-pelanggaran. Dalam komunikasi itulah setiap aturan atau nilai-nilai keluarga disampaikan. Keluarga yang memiliki kekurangdekatan hubungan antar anggota keluarga, hubungan yang tidak harmonis dalam keluarga, akan sangat sulit membicarakan hal ini dalam keluarga dan memungkinan timbulnya delikuensi pada anak remaja (Aroma, 2012).

Pada penelitian didapatkan hasil analisa bahwa ada hubungan Pola Asuh Orang Tua dengan konsep diri remaja tentang perilaku seksual di SMK Negeri di Kota Semarang. Hasil penelitian ini sama dengan penelitian Baldwin ,membandingkan keluarga-keluarga yang interaksinya bercorak demokratis dengan keluarga dimana pengawasan orang tua yang keras terhadap anak (otoriter). Ia memperoleh hasil bahwa semakin otoriter orang tuanya semakin berkurang ketaatan, timbulnya ciri-ciri pasifitas, kurangnya inisiatif, tidak dapat merencanakan sesuatu, daya tahan berkurang dan takut-takut. Sebaliknya sikap-sikap demokratis dari orang tua menimbulkan ciri-ciri berinisiatif, tidak takut-takut, lebih giat dan terencana, namun juga masih dimungkinkan untuk berkembangnya sifat-sifat tidak taat dan tidak mau menyesuaikan diri dari remaja tersebut. Sejalan juga dengan penelitian Wulandari "hubungan pola asuh demokratis dengan sikap terhadap perilaku seksual remaja" yang membuktikan bahwa ada hubungan signifikan antara pola asuh demokratis dengan perilaku seksual remaja. Apabila pola asuh demokratis diterapkan dengan baik maka tingkat perilaku seksual remaja akan rendah (Angelina, 2013).

Dimana dalam penelitian ini hubungan dari pola asuh orangtua yang demokratis dapat menghasilkan konsep diri yang baik, karena orang tua memberi kesempatan pada anak untuk mengatakan pendapat, keluhan, kegelisahan dan menjelaskan bagaimana anak diharapkan. Selain itu anak akan dihukum bila melakukan kesalahan. Akibatnya bagi remaja yang dalam asuhan demokratis merasa mendapatkan perhatian dari orang tuanya dan cenderung malu atau sungkan dalam melakukan tindakan yang tidak sesuai dengan kehendak orang tua. Dan anak merasa sangat berharga karena diberikan kepercayaan dari orang tuanya untuk melakukan hal yang tidak keluar dari batas kewajaran, sehingga remaja sangat berfikir teliti dan hati-hati dalam bertindak, begitu pula dengan perilaku seksual yang mereka ketahui dari keterbukaan orangtua sehingga membantu mereka dalam berteman atau bergaul (Asih, 2010).

Berbeda dengan pengasuhan otoriter, dimana orang tua mengontrol segala aktivitas anak dengan ketat, menuntut anak selalu patuh pada orang tua, membuat anak menyesuaikan diri dengan standar yang ditentukan oleh orang tua dan menghukum keras bila anak melanggar aturan, anak tidak dipuji saat mau melakukan sesuatu, serta tidak memperhatikan keinginan anak karena orang tua cenderung memaksakan kehendaknya. Akibatnya menyakitkan hati anak sehingga terkadang anak ngambek dan tidak melaksanakan perintah orang tua, menimbulkan rasa takut dan dendam, tidak adanya rasa kasih sayang kepada orang tua sehingga timbul perilaku agresi untuk menentang kehendak orang tua. Selain itu dalam aplikasi kehidupan sehari-hari, remaja yang dalam asuhan otoriter cenderung memunculkan perilaku agresi kepada lingkungan sekitar sebagai modeling dari perilaku orang tua kepadanya. Dalam penelitian ini dapat mempengaruhi konsep diri pada remaja yang buruk jika orangtua memberikan pengasuhan dengan sistem otoriter, sehingga 
mereka tidak bisa menceritakan dan terbuka kepada orangtua tentang perkembangan puberitasnya yang seharusnya dapat ditanyakan ke orangtua untuk mendapatkan nasehat yang baik (Khairunnisa, 2013).

\section{PENUTUP}

Responden terdiri dari 168 siswa laki-laki $(44,4 \%)$ dan 210 siswa perempuan (55,6\%), Pendidikan terakhir orangtua rata-rata tamat SLTA/sederajat, ayah $(46,6 \%)$ dan ibu (47,9\%). Pekerjaan orangtua paling banyak swasta $(44,4 \%)$ pada ayah dan (48,4\%) ibu tidak bekerja. Konsep Diri Remaja tentang perilaku seksual Baik sebanyak 258 orang $(68,3 \%)$ dan Buruk 120 orang (31,7\%). Pola Asuh orangtua Otoriter sebanyak 219 orang (57,9\%), Demokratis 159 orang (42,1\%), dan permisif tidak ada. Peer group Baik sebanyak 99 orang $(26,2 \%)$, dan peer group buruk sebanyak 279 orang (73,8\%). Ada hubungan Peer group dengan konsep diri remaja tentang perilaku seksual di SMK Negeri di Kota Semarang. ( $P=0,009$ $(\mathrm{p}<0,05), \mathrm{C}=0,134)$ Ada hubungan Pola Asuh Orang Tua dengan konsep diri remaja tentang perilaku seksual di SMK Negeri di Kota Semarang $(P=0,003 \quad(p<0,05)$, dengan $\mathrm{C}=0,153$ )

Penelitian ini hanya menggambarkan hubungan antara pola asuh orang tua dan peer group terhadap konsep diri remaja terkait perilaku seksual. Namun faktor lain yang berkaitan dengan konsep diri dalam hal perilaku seksual belum dilakukan. Sehingga saran untuk penelitian selanjutnya yaitu untuk meneliti tentang faktor lain yang lebih komprehensif yang berhubungan dengan konsep diri remaja tentang perilaku seksual brisiko baik secara kuantitatif maupun kualitatif.

\section{DAFTAR PUSTAKA}

Amaliyasari, Y., \& Puspitasari, N. 2008. Perilaku seksual anak usia pra remaja di sekitar lokalisasi dan faktor yang mempengaruhi. Jurnal Penelitian Dinas Sosial, 7(1): 54-60.
Angelina, D. Y. 2013. Pola asuh otoriter, kontrol diri dan perilaku seks bebas remaja SMK. Persona: Jurnal Psikologi Indonesia, 2(2).

Aroma, I. S., \& Suminar, D. R. 2012. Hubungan antara tingkat kontrol diri dengan kecenderungan perilaku kenakalan remaja. Jurnal Psikologi Pendidikan dan Perkembangan, 1(02): 1-6.

Asih, G. Y., \& Pratiwi, M. M. S. 2010. Perilaku prososial ditinjau dari empati dan kematangan emosi. Jurnal Psikologi UMK: PITUTUR, 1(1): 33-42.

BKKBN. 2008. Peran Orangtua dalam Pembinaan Remaja. Jawa Tengah: BKKBN.

Batubara, J. R. 2016. Adolescent development (perkembangan remaja). Sari Pediatri, 12(1): 21-9.

Desiyanti, I. W. 2015. Faktor-faktor yang berhubungan terhadap pernikahan dini pada pasangan usia subur di Kecamatan Mapanget Kota Manado. JIKMU, 5(3).

Dewi, N. S. 2010. Pengaruh Pendidikan Kesehatan Terhadap Perubahan Pengetahuan Dan Sikap Dalam Pencegahan Hiv/Aids Pada Pekerja Seks Komersial. Nurse Media Journal of Nursing, 2(1).

Fatchurahman, M. 2012. Kepercayaan diri, kematangan emosi, pola asuh orang tua demokratis dan kenakalan remaja. Persona: Jurnal Psikologi Indonesia, 1(2).

Gainau, M. B. 2009. Keterbukaan diri (self disclosure) siswa dalam perspektif budaya dan implikasinya bagi konseling. Jurnal ilmiah widya warta, 33(1), 95-112.

Hidayangsih, P. S., Tjandrarini, D. H., Mubasyiroh, R., \& Suparmi, S. 2011. Faktor-faktor yang berhubungan dengan perilaku berisiko remaja di kota Makassar tahun 2009. Buletin Penelitian Kesehatan, 39(2 Jun): 88-98.

Khairunnisa, A. 2013. Hubungan religiusitas dan kontrol diri dengan perilaku seksual pranikah remaja di MAN 1 Samarinda. Ejournal psikologi, 1(2): 220-229.

Mertia, E. N., Hidayat, T., \& Yuliadi, I. 2011. Hubungan antara Pengetahuan Seksualitas dan Kualitas Komunikasi Orangtua dan Anak dengan Perilaku Seks Bebas pada Remaja Siswa-Siswi Man Gondangrejo Karangnyar. WACANA, 3(6).

Munawaroh, F. 2012. Konsep Diri, Intensitas Komunikasi Orang Tua-Anak, dan Kecenderungan Perilaku Seks 
Pranikah. Persona: Jurnal Psikologi Indonesia, 1(2).

Nursal, D. G. 2008. Faktor-faktor yang berhubungan dengan perilaku seksual murid SMU Negeri di Kota Padang tahun 2007. Jurnal Kesehatan Masyarakat Andalas, 2(2): 175-180.

Pratami, I. N. F. W. 2011. Hubungan Keterpaparan Media Informasi Tentang Seks dengan Perilaku Seks Remaja Awal pada Siswa di SMP Semarang. Jurnal Dinamika Kebidanan, 1(2).

Respati, W. S., Yulianto, A., \& Widiana, N. 2006. Perbedaan konsep diri antara remaja akhir yang mempersepsi pola asuh orang tua authoritarian, permissive, dan authoritative. Jurnal Psikologi, 4(2): 119-138
Rahmania, H. N., \& Putra, M. G. B. A. 2006. Hubungan antara persepsi terhadap pola asuh otoriter orang tua dengan kecenderungan pemalu (shyness) pada remaja awal. INSAN, $8(3)$

Suwarni, L. 2009. Monitoring parental dan perilaku teman sebaya terhadap perilaku seksual remaja SMA di kota Pontianak. The Indonesian Journal of Health Promotion (Jurnal Promosi Kesehatan Indonesia), 4(2): 127-133.

Widyastuti, E. S. A. 2009. Personal dan sosial yang mempengaruhi sikap remaja terhadap hubungan seks pranikah. The Indonesian Journal of Health Promotion (Jurnal Promosi Kesehatan Indonesia), 4(2): 75-85. 